\title{
THE ROLE AND IMPORTANCE OF STRATEGIC BUDGETING FOR COMPETITIVENESS OF THE AGRIBUSINESS SUPPLY CHAIN ${ }^{1}$
}

\author{
Bojan Savić2, Zorica Vasiljević3 ${ }^{3}$ Nikola Popovićc
}

\begin{abstract}
Summary
Rapid challenges and changes that are an integral part of the business environment require from the enterprises to plan carefully their business, as well as to assess the probability of occurrence and outcome of future events. The importance of this approach is even more evident in the field of agribusiness, which is characterized by the increasingly unfavorable business conditions along with numerous specificities and limitations typical for agricultural activity. It is primarily about the growing business costs on one side and disproportionate changes in the level of agricultural products' selling prices on the other one. The enterprises form a supply chain in order to reduce risk and uncertainty, to realize the production of high-quality products at competitive prices, to maintain and increase the market share. The realization of such complex goals requires an adequate approach to the budgeting process. The aim of the paper is to highlight the importance, achievements and challenges of budgeting as an instrument of management accounting and strategic budget in order to support management in their efforts of acquiring and improving the competitiveness of the entire supply chain.
\end{abstract}

Key words: management accounting, strategic budget, supply chain, agribusiness sector, competitiveness.

JEL: $M 41, Q 13, Q 14$.

1 The paper is a result of the researching project No III-46001 «Development and application of new technologies in production of competitive food value-added products for domestic and foreign markets-Let's make wealth from the wealth of Serbia, and project No. III46006 «Sustainable agriculture and rural development in the function of implementing the strategic goals of the Republic of Serbia within Danube region“, financed by The Ministry of Education, Science and Technological Development of the Republic of Serbia.

2 Bojan Savić, PhD., Teaching Assistant, University of Belgrade, Faculty of Agriculture, Nemanjina Street no. 6, 11080 Belgrade Zemun, Republic of Serbia, Phone: +381 112615 315 /Ext. 211, E-mail: bsavic@agrif.bg.ac.rs

3 Zorica Vasiljević, PhD., Full Professor, University of Belgrade, Faculty of Agriculture, Nemanjina Street no. 6, 11080 Belgrade Zemun, Republic of Serbia, Phone: +381 112615 315 /Ext.412, E-mail: vazor@agrif.bg.ac.rs

4 Nikola Popović, M.Sc., Teaching Assistant, University of Belgrade, Faculty of Agriculture, Nemanjina Street no. 6, 11080 Belgrade Zemun, Republic of Serbia, Phone: +381 112615 315 /Ext. 215, E-mail: nikpop@agrif.bg.ac.rs

EP 2016 (63) 1 (295-312) 


\section{Introduction}

The efficient management of an enterprise as well as the realization of defined goals requires that a number of decisions should be adopted by the enterprise management. The crucial goal of both modern enterprises and stakeholders is creation of the value for owners, and that is why the necessary precondition for realization of this goal is realization of the profitable business operations in the long run.

In an effort to achieve and maintain profitability, farmers in the Republic of Serbia are faced with numerous challenges, which are primarily manifested in the form of inadequate technical and technological equipment, a high degree of uncertainty in agricultural production subsidizing, the risk of climate changes and weather conditions, the changes in legal regulations, low purchasing prices, a buyer's monopoly, etc. All mentioned items contribute to the creation of an environment in which the business planning has become very complex, since the supply, but also the demand for the products have become extremely volatile, and that the domestic agribusiness sector enterprises are frequently confronted with a struggle for mere survival. Hence, the solution can be identified, among other things, in the interconnection of producers and consumers in the so-called supply chains. Such systems are often formed on the basis of contracts that precisely define the rights and obligations of all participants in the supply chain.

A key advantage of the above-mentioned approach is reflected in the fact that producers produce for the known buyer, thus uncertainty regarding the sales of products and the overall business operations have been significantly reduced. The main motives for establishment of the supply chains are contained in strengthening the potential to realize opportunities in the environment, to minimize unfavorable effects concerning a number of risks and to improve the competitive position of all participants. However, the efficient functioning of the supply chain in general, and in the agribusiness sector in particular, assumes the participation and support of many entities that are located between producers and consumers, which should contribute and ensure that products without difficulties find their way to the final consumers.

In order to design the future business operations and achieve profitability, management has at disposal different budgeting techniques. They are used for different purposes, and beside defined goals and business conditions, the choice is determined by the type of activity the enterprise is dealing with. This further implies that it is necessary to adjust the budgeting process to the specificities of the business operations for the enterprises in agribusiness sector, i.e. for particular types of agricultural production, processing and distribution of products within this sector, but also to the locations where business operations are conducted.

The goal of this paper is to highlight the importance of budgeting implementation as an instrument of management accounting in the agribusiness sector in gaining and maintaining a competitive advantage not only of individual enterprises, but the entire agribusiness sector supply chains, with special reference to the strategic budget. This will offer to the local managers who manage the complex agribusiness systems a powerful instrument which could be significant support in their efforts to increase 
the flexibility and productivity of the system and to compete successfully with other producers at the global market and to achieve sustainable and profitable business.

\section{Material and Method}

In this paper there were used the methods that best reflects the character of the analysis given in the titled topic. In an effort to examine and analyze the budgeting process as an instrument of management accounting and to carry out strategic interpretation of the strategic budget as the key instrument used by management for the purpose of directing business activities and decision-making, there were applied scientific research methods such as descriptive method, methods of analysis and synthesis, method of systematization, comparative method, inductive reasoning method and "desk research" method. The contribution of this paper is reflected in the review and analysis of the budgeting process and the strategic budget as an instrument of the management accounting, which currently are not widely represented in domestic agribusiness enterprises, as well as to consider the specificities of their application in complex systems like the supply chains. By this analyze it is pointing to their potentials to contribute to a higher degree of efficiency, flexibility, competitiveness and finally to the business profitability. The sources of literature used for this research were the domestic and foreign scientific literature from the domain of the considered issues, as well as the data sources available on the Internet websites.

\section{The Supply Chain in the Agribusiness Sector}

The need of the supply chain establishment is conditioned by the trends that design the business environment, such as an imperative of focusing on customers, development of the information society and globalization of market. The presence of these trends has caused changes in strategies for achieving and sustaining competitive advantage of numerous enterprises, while requiring at the same time the adequate concept of value chain management (Ivanov, Sokolov, 2010). In a business environment where the production orientation of an enterprise is dominant, the focus is put on products, all efforts are directed toward maximization of the production volume, the business planning has operational character, while an exchange of information within enterprise is quite limited. Contrary to this, in the market-oriented enterprises the focus is on finding optimal combinations between markets and products, the efforts are focused on maximization of value added, the planning has strategic character, the enterprises are trying to connect mutually, while the information has been freely exchanged not only at the level of an enterprise, but also within the whole supply chain (Lindgreen, Hingley, 2010). The market-oriented agribusiness enterprises put additional emphasis on respecting rigorous standards of quality and safety, as well as on the environmental regulations.

The main motives for establishment of the supply chains are contained in strengthening the potential of the entire system to realize the opportunities in the environment, to minimize unfavorable effects coming from the numerous risks and to improve the competitive position of all participating enterprises. However, the efficient functioning 
of the supply chain assumes the participation and support of many entities that are located between producers and consumers, including the government support as well, in order to enable the products find their way to the final consumers without difficulties. First of all those are various transportation, freight forwarding, warehousing, insurance, marketing, wholesale, retail and other specialized organizations, which through mutual cooperation should contribute to be overcome the spatial and temporal gap between producers and final consumers (Malinić, Janković, 2011).

The first step in establishment of the supply chain in agribusiness is an analysis of the existing trade system and environment (flows of products, the level of trade, governmental policies and other circumstances) aiming at identification of factors that are critical for success of the supply chain. This includes the implementation of a SWOT analysis to identify strengths and weaknesses of potential supply chain, but also possible opportunities and threats that exist in the environment. On the basis of information that are result of such analysis, potential participants make a decision on whether to include in the supply chain. If they choose to participate in it, then define their roles, functions and mutual relationships in the supply chain (Rockel et al., 2002).

If, for example, it is analyzed the process of the milk production and processing, it is indisputably that the path from the raw milk as an input to the final product rather long and as such it includes the following: production and delivery of milk by the farmers, raw milk reception and cooling of milk in collection stations, transport of milk to dairy plants, milk processing (filtration, separation, standardization on the basis of fat content, pasteurization, homogenization, application of different bacterial cultures, finalization), packing and storage of dairy products and their further shipping to the wholesale centers, delivery to the retail outlets based on contracts or export to the foreign markets (Bachev, 2011).

With regard to the producers of basic inputs such as milk, meat, fruit and vegetables for the production of the food industry, in addition to the challenges of agricultural production itself, the successful placement of products includes even the issues of adequate transport, storage and protection from the product spoiling. Compared to their competitors from developed countries, the Serbian producers are additionally faced with the challenges of underdeveloped transportation infrastructure that leads to the emergence of risks in terms of quality and safety of products as well as the related occurrence of losses due to the product shrinkage and spoilage. Therefore, when it comes to the production of agricultural and food products, it is necessary to include in the supply chain even the cold stores, i.e. the "cold chain", which represents the specificity compared to the supply chains in other sectors.

Activities of mentioned economic subjects undoubtedly have an impact on consumer satisfaction. Thus, for example, customers will be satisfied only if the products are delivered in optimal deadlines, if the products have high quality (in the case of food products the important attributes are freshness, flavor, taste) and at an affordable price. The above-mentioned requirements indicate that achieving a high level of customer 
satisfaction is assumed to be optimally managed by suppliers, by the product quality, then to be synchronized the distribution channels, to manage effectively by the customers, which all together require a high degree of coordination and collaboration among the participants. In other words, the production and sales of products have become a challenge which surpasses individual enterprises-producers and as such they have been positioned in the center of interest of the top management for the entire supply chain. Hence, the supply chain should integrate all key business functions (the product design, production, marketing, sales, finance, IT, logistics), as well as the business processes within individual enterprises, but also between all the companies that participate in the supply chain (Ayers, 2006). In other words, the functions of individual members at the level of the supply chain are viewed as the business processes. Only in this way each participant will provide an appropriate contribution to the creation of superior value of the final product, and thus the value for customers.

The advantages of involvement in the supply chain are the following: reducing the risk of losses arising in transportation and storage, the sales increase, providing access to the modern technologies, capital and specialized knowledge, better information about the flow of products and developments in the market, then in a more effective quality control and product safety, the risk sharing between partners, an increase of revenues and profits, and finally, in a higher sum of total created value (Rockel et al., 2002).

In order the listed business advantages within the supply chain should be successfully implemented, it is necessary to manage them efficiently. Production for known customer demands abandoning of the traditional approach (which is characterized by production for the storage) and introducing of so-called Lean concept, Just-in-time system of the stock management, which further assumes a high level of collaboration in the supply chain, effective management of orders, timely deliveries, as well as the high level of customers' satisfaction (Ross, 2011).

A key task of supply chain management is the planning and management of the supply processes (suppliers), then of the resources' transformation (production), as well as of the activities in the field of logistics. However, it should not be neglect the necessity of the customers' management, since by the strengthening of their competitiveness it is contributed not only to the strengthening of enterprises-producers, but also to the other participants in the supply chain.

The above clearly shows the role and importance of the budgeting process for the purpose of efficient management and implementation of the defined supply chain goals. Namely, the budget has the planning function but also the control one. Through the budgeting process it is allowed that the objectives and strategies of the supply chain are translated into concrete activities of all participants. On the other hand, by measuring of the accordance between the budgetary defined and implemented performances, it is possible to control the business efficiency for particular participants, to quantify their contributions, to determine responsibility for the achieve results and to undertake the necessary corrective activities. 


\section{The Role and Importance of Budgeting and Strategic Budget in the Supply Chain}

The budgeting can be defined as the process by which management projected the future of an enterprise. The budget as a direct result of this process represents a plan of the enterprise activities for a defined period of time. More precisely, the budget may include the financial and non-financial projections of planned activities, depending on whether it comes to operational or financial budget. Thus, for example, the budget shows the necessary and available types and quantities of resources which represent the basis for realization of defined objectives (direct and auxiliary material), then the anticipated quantity volume of production and sales, number of new products, number of employees, etc. The listed non-financial data are the basis for determining the financial implications of the planned activities, i.e. they are an assumption for projections of revenues, expenses, profits and investments for the given time horizon. The cited financial effects get their materialization in the form of projected financial statements so- called pro-forma financial statement (Mowen et al., 2014).

Figure 1. Budgeting framework - the supply chain perspective

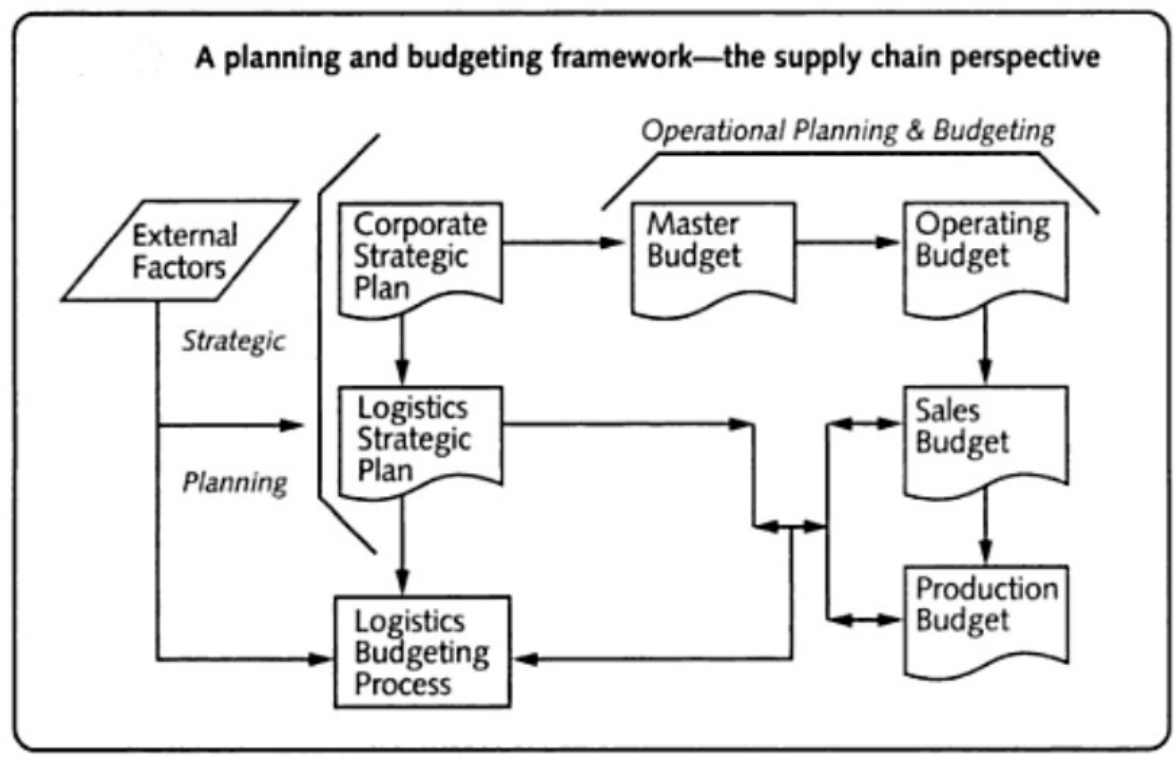

Source: Tompkins, Harmelink, (2004). The Supply Chain Handbook, Tompkins Press, $p$. 58 .

As it can be observed from the Figure 1, the top management of the supply chain first defines the strategic direction, and then the long-term objectives on the basis of which determines the strategy for their implementation. These long-term objectives have to be decomposed to the series of the short-term goals. The budget is used as an instrument of strategic planning in order to quantify the short-term goals (Toit et al., 2007). In this process the management accounting has an important role primarily in the form 
of providing adequate information support. The management accountants together with the management plan performances of the member enterprises, but the planning is also done at the level of the supply chain as a whole, it primarily starts from the past performances and expected changes in the future. The most obvious contribution of accountants in this process is reflected in the establishment of the standard operating costs. Based on the achievements of subordinated managers and comparisons with the expected financial and non-financial results, the management accountants determine the created deviations from the defined results, investigate the causes for that, which provides an informational basis for determination of corrective actions to be taken in the future. At the same time, on the basis of realization and planned activities that are projected the results for the upcoming period. The objectives of the budget can be summarized as follows (Bazley et al., 1999):

- The compel planning;

- Co-ordinate functions within an organization;

- Communication tool;

- Basis for responsibility accounting;

- Tool for resource allocation;

- Basis for a control mechanism;

- Motivate to employees.

As an instrument of management accounting, in practice, it is possible to apply different budgeting types - the strategic or the long-term budgeting, the operational or the shortterm one, the "zero" budgeting, the fixed or flexible one, the activity-based budgeting, budgeting based on value, performance-based budgeting and other contemporary forms of budget. Their importance lies in the possibility to perceive customer needs, the potential market share of the enterprise, to identify the problems in the supply of raw materials and other inputs, to determine surpluses and shortages of labor, all of which should contribute to an improvement of the business efficiency. A series of partial budgets is necessary to be mutually harmonized and integrated into the master (main) budget which includes the business and financial implications of the planned activities for a defined period of time (Stevanović et al., 2008).

Because, as outlined before, the budget at the same time represents a diagnostic i.e. the control, but also an interactive mechanism for decision-making, in the master budget it arises often a challenge to be harmonized efficiency and effectiveness, the control and creativity, undertaken risks and consequences. Three elements that have a key influence on the behavior of management in the budgeting process include: difficulties to be reached the defined benchmarking, the degree of participation of all managers in defining the budget, as well as the relationship between the realized and planned performances (Camillus, 1986).

To accomplish this goal, the budget must be synchronized with the nature of the business activities of enterprise. This means that the time horizon of the budget necessary to EP 2016 (63) 1 (295-312) 
harmonize with duration of the operating cycle of the observed enterprise or supply chain. In the manufacturing enterprises this cycle usually lasts less than one year. An additional factor when choosing the time horizon is the degree of uncertainty that is present in the business environment of an enterprise. Higher uncertainty implies a shorter planning horizon in order to ensure a satisfactory degree of accuracy in planning (Camillus, 1986).

The connection between the strategy and strategic budgeting can be seen in the following examples (Dressler, 2004):

- If an enterprise pursues an innovation strategy and approaches revenue growth through new products, funding for R\&D projects needs to be stronger than usual;

- If an enterprise choice an internationalization strategy with multiple market entries abroad, the funding for new marketing activities needs to be promoted;

- If a company drives a rigid cost leadership strategy, capital investments need to be monitored closely.

Strategic budgeting is focused on the realization of the strategic goals of an enterprise. Its essence consists of a selection of appropriate projects and programs by which the defined enterprise strategies have been implemented. As a result of the strategic budgeting occurs strategic budget (for the period of over five years) in which there have been presented the financial implications of appropriate strategic options (Janjić, 2011).

The strategic budgeting is a key instrument for realization of the cost leadership strategy and acquisition of the competitive advantage of the supply chain. Namely, in the modern business environment, in the efforts to win and maintain the market share and to improve the performance, in addition to the individual enterprises also mutually compete even the entire supply chains. The specificities of strategic budgeting are expressing in the following (Taylor, Rafai, 2003):

- Collecting of the preliminary budgets by the individual departments (of the member companies);

- Reducing the proposed budgets by a certain percentage, which has been defined by the top management of the supply chain;

- Aggregation of all savings in the budgets of individual members and their expression in the budget of the group;

- If some of the supply chain member needs additional capital, it is necessary that management of that member explains and justifies the requirements through discussion with the management of other members. The funds are available from the realized savings of other members in the form of so-called budget buffer.

The strategic budget as a rule has been prepared by the larger and more complex enterprises (including the supply chains) in order to be included in them the financial implications of the planned capital investments, investments into maintenance and expansion of existing facilities, developing of new markets, diversification of products 
and processes (Stevanović et al., 2008).

Although essentially different, the strategic management and the budgeting are activities that are closely linked. Namely, they are aimed at achieving superior performance of the businesses subject or supply chain. In doing so, budgeting relates to the allocation of financial resources to the business units, activities and investments, projections of revenues and expenditures, examination of the projected capital expenditures. The task of strategic management is to determine the course of the supply chain activities, to identify strategies for market presentation and to organize internal activities i.e. the activities of the enterprises that are members of the chain. On the other hand, budgeting should enable the efficient allocation of financial resources and monitoring of achieved performances. Although the process of creating a strategy precedes the budgeting process, the efficient implementation of the strategy requires guidelines from the budget. Only in this way it will be enabled that realization of the objectives at the same time will be accompanied by improvement of the financial performances (Blumentritt, 2006). Namely, it is possible that excessive investments cause the financial stress, but also that financial conditions should be improved thanks to the future operations. Hence, as an imperative it appears a need for harmonization of strategic management and budgeting process.

In support of the previous assertions there are the proposals given by some authors that the process of strategic management and budget should be integrated. In fact, due to the turbulent business environment and errors that may arise in the case of the past data extrapolation, it is proposed the flexible budgeting, which respects even the expected changes. Integrating of strategic management and budget provides the ability to achieve projected performances, i.e. to simultaneously improve the financial and strategic supply chain performances. In addition, the strategic performances related to the implementation of goals such as winning new clients, introducing new products and services, improving the business efficiency. The financial performances comprise the financial aspects of the business such as revenue growth, margins, return on investments (Golsby-Smith, 2011).

Linkage of strategic management and budget can be shown through the following series of steps (Drury, 2008):

1. Defining the objectives of the supply chain as a whole;

2. Identifying the potential courses of action (i.e. strategies);

3. Evaluation of strategic options;

4. The choice of an alternative course of action;

5. Implementation of the long-term plan in the form of an annual budget;

6. Monitoring of the achieved results;

7. Taking over the corrective activities in case of significant deviation of the achieved results. 
The first four steps are related to the long-term planning, while the remaining three activities are under the jurisdiction of the annual budgeting process.

The previous arguments clearly show the importance of including financial managers in the process of the supply chain planning and budgeting. In fact, their role is not only in the financial, accounting and business activities, but they are expected to provide a holistic view of the organization. In order to ensure a strategic and competitive advantages of the supply chain, the financial management should contribute that the goals of the organization should be focused towards the creation of the economic value added - EVA. This will allow that an appropriate course of action should be chosen, to be improved the efficiency and effectiveness of operations. Based on the analysis of historical performances, the financial manager will be able to gain insight into the future details such as projected revenues and costs, gross margin etc. (Ramachandran, 2012).

The supply chain management makes decisions about the use of available resources of its members and directly affects their financial results. Hence, it is important to consider the effects of the respective decisions on financial targets and related indicators of the enterprise. Decisions made on the level of the supply chain directly affect revenues (time of introduction a new product on the market, timeliness of delivery, quality of product, return of the product), the production costs (transportation costs, costs of inventory management, number of suppliers, packaging, waste) as well as the overhead administrative and sales costs of particular members - the costs of guarantees, costs of sales, costs of documentation, control of the exchange rate etc. (Visner, 2010).

In order to perceive the effectiveness and efficiency of activities within a supply chain, it is necessary to measure its performances. Measuring primarily aims to establish a deviation from the defined benchmarking. Namely, in the process of budgeting the management defines the target size, while by measuring there have been determined the positive and negative deviations that provide valuable information for the future decisions and actions. The performance of the supply chain operations that are monitored can be qualitative and quantitative; they can then have a cost and non-cost character, the strategic, operational and tactical focus. When it comes to the cost performance indicators, they relate to the costs of distribution, costs of the stock shortages, the costs of used resources, time of production, the number of timely deliveries etc. (Ghosh et al., 2014).

The system of remuneration of management on the basis of the savings realized through strategic budgeting contributes to efforts aiming at reducing the costs should be realized through the permanent review of processes and activities in the enterprise, reducing of waste and increasing of efficiency. This can directly improve the financial but also the environmental performances of the supply chain.

According to Kurien and Quereshi (2011) the measuring of the supply chain performances should be based on three pillars:

- Measuring of resources (total costs, inventory level, the need for personnel, engaged equipment, consumed energy, costs); 
- Measuring the output refers to the quality and quantity of final products and the reaction of customers;

- Measuring offlexibility refers to the ability to adjust the volume and delivery schedules fluctuations, which are determined by suppliers, manufacturers and customers.

It is of particular importance that the budget fits into the broader financial plan of the supply chain, in order to be achieved the defined financial targets and deadlines for their achievement.

\section{Challenges of Budgeting in the Agribusiness Supply Chain}

As already pointed out, budgeting is the process of designing business for the coming period. In this process it has been often started from the past events and achievements that have been then adjusted in accordance with the dynamics of the business environment and forecasts of the management. What is observed in recent years is that business conditions are becoming increasingly complex, while the changes increasingly turbulent. In this regard, the challenges anticipated for agribusiness sector are moving in the following direction (Boehlje, Roucan-Kaneb, Bröring, 2011):

- Increased risk and uncertainty of the business environment;

- The development and adoption of new technologies and innovation is the key for the business success;

- The timely response to the changes in the industrial structure and actions of the competing enterprises and supply chains represents the precondition for maintaining and increase of the market share.

In recent years, risk and uncertainty are expressed to such an extent that they gain strategic importance for business. Exposure to the risk and uncertainty can occur based on the events that could cause the disruption of business and lead to the loss of the key personnel. Therefore in modern business conditions, a special attention must be paid to the diffusion of knowledge at the organizational level as well as to the creation of "the learning organization". The adoption and application of knowledge as well as an innovative thinking could replace limitations of certain resources and enable "to achieve more with less (inputs)". The enterprises and supply chains mutually compete by knowledge, and not by products, which means that progress can be achieved only with continuous learning (Vasiljević, Savić, 2013).

In the area of financing, there is the risk of rising interest rates and a high level of indebtedness, which could jeopardize the liquidity and solvency not only of the member enterprise, but also of the entire supply chain. Furthermore, unfavorable market conditions may generate exposure on the basis of pressure in the area of sales prices due to the approval of the discount by the competition, enlarging of customers and strengthening of their bargaining power. In the area of technology, the risk appears due to the fact that the provision of modern technologies requires significant capital expenditures, while on the other side the commercialization of new products takes place relatively slowly, which leads to the conclusion that for the capitalization of advantages 
it is necessary a longer time horizon, but in addition the significant liquidity reserves for the smoothly progress of business (Boehlje, Roucan-Kaneb, Bröring, 2011).

Efficient supply chain management begins with planning of the product life cycle and continues by planning of inputs' delivery by the suppliers, by the product planning, territorial distribution and management of retail stores, delivering of invoices to the customers and their payments. In this process a central place among the business functions belongs to the production. Therefore, the most significant is making of the production budget, which has to be based on the sales plan. In other words, all value channels start with conversion of inputs and components throughout the process of production into the final products. The starting premise of this process undoubtedly makes an appropriate choice of technical and technological equipment of the enterprise-producer as equipment and technology determine parameters such as the size of the enterprise capacity, the amount of the costs, the product quality, the time cycle and limits. In addition, production for the well-known customer demands abandoning the traditional approach, which is characterized by the production for the warehouse and introduction of so-called Lean concept, Just-in-time inventory management system, which in turn require a high level of collaboration in the supply chain, the effective management of orders, timely deliveries and high level of customers' satisfaction (Ross, 2011).

Additional problems in the agribusiness sector can arise if there is a high degree of dependence on individual suppliers, which not only reduces the bargaining power, but it appears even the risk of exposure to the rising input costs. Hence the goal of establishing the supply chain just to overcome such unfavorable effects. However, the areas where arise the systematic risks which cannot be diversified are the political situation and regulations, which are manifested in the form of the changes in legislation that may impose additional restrictions in the business, then the changes in the tax policy, the introduction of rigorous environmental regulations and alike.

In addition to the structural changes of the business environment that make the implementation of the budget extremely complex, certain challenges are directly linked with the budget creating procedure itself. Hence, those elements must be respected through their assessment, evaluation and testing of the effects from the budgeting process and the planned figures. These are events such as changes in selling and purchasing prices, defining of the transfer prices, and the appearance of inflation and exchange rate changes.

The dynamics of the business environment has been followed by the price dynamics as well. The price war that has been waged by the enterprises and supply chains in order to regain the customers, imposes challenges in the budgeting process. Because of the mentioned variability in the agricultural products' prices on the one hand and the food products' prices on the other hand, it is necessary to design several scenarios for different levels of costs and selling prices, so that in the short term could be made the necessary corrections and supplements to the budget. 
Other important aspects of budgeting in the supply chain are the transfer prices. Namely, they affect the profitability of different forms of foreign business operations in the global supply chain. Although it is the price at which there are exchanged the goods and services within the supply chain, from the point of view of the individual enterprise it represents an uncontrollable variable, while at a higher hierarchical level it is controlled item. The issue of transfer prices represents an element that has been determined by headquarters of the supply chain, while they have been actualized by the accounting. Through the transfer prices there could be performed managing and structuring of transactions between members of the supply chain, also it could be affected the level of the resources' costs and allocation of profit between the members. When budgeting in an international environment, the transfer prices can provide numerous benefits to the enterprises members of the chain in the form of tax relief through the overflow of profits in the countries in which there are applied the lower tax rates, lower custom duties, avoiding of exchange rate control in the case of profit repatriation, etc. (Seppala, Kenney, Ali-Yrkko, 2014).

A significant challenge for the supply chains that operate in a global environment represents the change in the exchange rate since it causes three forms of exposure: translation exposure, transaction exposure, as well as the economic exposure. Translation exposure affects the financial statements during development of the budget. Namely, during the budgeting, the management starts from the expected future value of the exchange rate. Any deviation from the expected exchange rate directly affects the level of realized performances. This is because any change in the exchange rate requires adjustments in the policy of selling prices both in the domestic and foreign markets, as well as their reduction or increase, which further has implications on the volume of realized sales. However, apart from the selling prices' changes, with the change of exchange rate they are also changing the purchasing prices, i.e. the input prices, which directly affect the business results. Hence, in such circumstances it should be considered the switching from the foreign suppliers to the domestic ones, when it is possible, in order to provide lower input prices. The transaction exposure stems from the transactions with the foreign business subjects (such as unhedged contracted cash flows), repatriation of profits, as well as an acquisition and sales of foreign assets. In conditions when the cash flow from abroad is significant, it is recommended to draw up a special cash flow budget that will be generated abroad. Finally, economic exposure stems from variations of uncontracted cash flows due to changes in exchange rate. The importance of the economic exposure from the standpoint of budgeting refers to the fact that with the exchange rate changes it is necessary to make the harmonization of marketing strategy in terms of the price policy, market segmentation, promotional activities, set of the sales strategies (Rivera, Milani, 2011).

Previous paragraphs speak in favor of a flexible approach to budgeting in order to take into account trends and future developments, as well as circumstances that have implications for the market position, flexibility and competitiveness of supply chains. This is because the different lines of production are characterized by different time 
horizon. Differences exist not only between plant and animal production, but also within them, e.g. within the plant production the distinction should be made between say fruit and crop products. The differences are primarily caused by the level of necessary investments, the required equipment, the type of production (extensive vs. intensive one), territory on which the production takes place, the climatic conditions and other factors. Their comprehensive consideration and appreciation should result in establishment of realistic budgets, their more complete realization and improvement of the business efficiency. The final objective of these efforts is the maximization of the created value for customers and other stakeholders including the owners.

\section{Conclusion}

The principal motives for establishment of the supply chains are contained in the efforts to realize the opportunities in the environment, to minimize unfavorable effects based on the numerous risks and to improve the competitive position of all member enterprises. These benefits are contained in the following: reducing of risk in transportation and storage, in an increased sales, in providing access to the modern technologies, capital and specialized knowledge, in a better flow of information about product' flows and developments in the market, in the more effective quality control and product safety, in the sharing of risk between the partners, in an increase of revenues and profits, and finally, in a greater sum of totally created value.

The process of budgeting is seen as a strategic instrument for the acquisition and maintenance of competitive advantages both of enterprises and entire supply chains. The budget as a direct result of this process represents the plan of business activities for a defined period of time. The top management of the supply chain first defines a strategic direction, and then the long-term objectives on the basis of which determines the strategy for their implementation. Through the budget, the cited long-term goals have been broken down into a series of objectives. In practice, it is possible to apply different types of budgeting - strategic or long-term, operational or short-term, "zero" budgeting, fixed or flexible, activity-based budgeting, value-based budgeting, performance-based budgeting and other contemporary forms of budget. Their importance lies in the possibility to perceive customers' needs, potential market share of the enterprise, to identify the problems in the supply of raw materials and other inputs, to identify the labor surpluses and shortages, which all together should contribute to an improvement of the business efficiency.

To accomplish its goal, the budget must be synchronized with the nature of the enterprise business activities and the supply chain. This means that the time horizon of the budget is necessary to be aligned with duration of the operating cycle. The strategic budgeting represents a key instrument for realization of the cost leadership strategy and gaining of the supply chain competitive advantage. Namely, in the modern business environment, in the efforts to win and maintain the market share and to improve the performances, there are competing not only individual enterprises but the entire supply chains. The strategic budget has been usually prepared with an aim to include the 
financial implications of the planned capital investments, investments in maintenance and expansion of existing facilities, development of the new markets, diversification of products and processes. The advantages of strategic budgeting reflected in the relatively simple implementation, improved communication between members of the supply chain, the lower level of total spending and a significant reduction of costs. Those efforts towards reduction of costs do not compromise the quality or quantity of production, since the savings have been achieved by those members where this is possible, and such released funds are given at disposal to those members that have justified needs for additional capital.

In order to perceive the effectiveness and efficiency of activities within a supply chain, it is necessary to measure its performances. Measuring of performances primarily aims to determine deviations from the planned results. By measuring they are determined the positive and negative discrepancies that provide valuable information for future decisions and actions.

The challenges of budgeting in the agribusiness supply chain are resulting both from the structural changes and certain monetary phenomena such as inflation, changes in interest rates, changes in exchange rates and the associated price fluctuations.

The high degree of coordination and collaboration between the members of the supply chain should contribute to the establishment of realistic budgets, their successful implementation, then to the achievement of the cost leadership as well as to the creation of greater value and achievement of the competitive advantages.

\section{Literature}

1. Ayers, J. (2006): Handbook of Supply Chain Management (ISBN 10: 0-84933160-9). Auerbach Publications, New York.

2. Bachev, H. (2011): Dairy Supply Chain Management in Bulgaria, The IUP Journal of Supply Chain Management, IUP Publications, Vol. 8, No. 2, pp. 3961, Hyderabad.

3. Bazley, M., Hancock, P., Berry, A., Jarvis, R. (1999): Contemporary Accounting: A Conceptual Approach (ISBN 017 0094960). Nelson Thomson Learning, South Melbourne.

4. Blumentritt, T., (2006): Integrating strategic management and budgeting, Journal of Business Strategy, Emerald Group Publishing Limited, Vol. 27, No. 6, pp. 7379, Bingley.

5. Boehlje, M., Roucan-Kaneb, M., Bröring, S. (2011): Future Agribusiness Challenges, International Food and Agribusiness Management Review, International Food and Agribusiness Management Association, Vol. 14, No. 5, pp. 53-82, Washington.

6. Camillus, J. (1986): Strategic Planning and Management Control: Systems for Survival and Success,.(ISBN 0-669-10315-2). Maxwell Macmillan Canada, Inc. 
Ontario.

7. Dressler, S. (2004): Strategy, Organization and Performance Management - from basics to best practices, (ISBN: 1-58112-532-1). Universal Publishers, Boca Raton.

8. Drury, C. (2008): Management and Cost Accounting (ISBN 978-1-84480-5662). South Western Cengage Learning, London.

9. Ghosh, A., Das, S., Deshpande, A. (2014): Effect of Responsiveness and Process Integration in Supply Chain Coordination, The IUP Journal of Supply Chain Management, IUP Publications, Vol. 11, No. 1, pp. 7-17, Hyderabad.

10. Golsby-Smith T. (2011): Is your budgeting process killing your strategy?, available at: https://hbr.org/2011/01/is-your-budgeting-process-kill, accessed: 14.02.2015.

11. Ivanov, D., Sokolov, B. (2010): Adaptive Supply Chain Management (e-ISBN 978-1-84882-952-7). Springer, Chemnitz.

12. Janjić, V. (2011): Bihejvioristički aspekti procesa budžetiranja u preduzeću, Računovodstvo, Savez računovođa i revizora Srbije, No. 1-2, pp. 57-67, Beograd.

13. Kurien G., Quereshi M. (2011): Study of performance measurement practices in supply chain management, International Journal of Management and Social Sciences, SPEAK Foundation, Vol. 2, No. 4, pp. 19-34, Shahdara.

14. Lindgreen, A., Hingley, M. (2010): Market Orientation: Transforming Food and Agribusiness Around the Customer (ISBN 978-0-566-09208-4). Glower Publishing Limited, Surrey.

15. Malinić, S., Janković, M. (2011): Integrisano upravljanje troškovima u lancu distribucije: strategijski pristup $i$ upravljačko-računovodstvena podrška, Računovodstvo, Savez računovođa i revizora Srbije, No. 7-8, pp. 11-24, Beograd.

16. Mowen, M., Hansen, D., Heitger, D. (2014): Cornerstones of Managerial Accounting (ISBN 978-1-305-10396-2), Cengage Learning, Boston.

17. Ramachandran, R. (2012): The Strategic CFO and Supply Chain Planning: Moving Beyond Numbers, WIPRO Applying Though, available at:https://www. google.rs/?gws rd=cr,ssl\&ei=8YqaVZzrOIHmsAGgk4QI\#q=The + Strategic $+\mathrm{C}$ FO+and+Supply+Chain+Planning, accessed: 19.03.2015.

18. Rivera, J., Milani, K. (2011): Budgeting for International Operations $>$ Impact on and Integration with Strategic Planning, Management Accounting Quarterly, Institute of Management Accounting, Vol. 12, No. 4, pp. 1-13, Montvale.

19. Rockel, J., Willems, S., Bosche, D. (2002): To Stimulate Cross-Border Trade in Developing Countries and Emerging Economics, World Bank Paper, available at:http://wwwwds.worldbank.org/external/default/WDSContentServer/ $\mathrm{WDSP} / \mathrm{IB} / 2005 / 04 / 05 / 00009034120050405142222 / \mathrm{Rendered} /$ PDF/318960AgriSupply0Chain0Mgmt.pdf, accessed: 21.02.2015.

20. Ross, D. (2011): Introduction to Supply Chain Management Technologies (ISBN 
13: 978-1-4398-3753-5). Taylor and Francis Group, LLC, Boca Raton.

21. Seppala, T., Kenney, M., Ali-Yrkko, I. (2014): Supply Chain Management: An International Journal, Emerald Group Publishing Limited, Vol. 19, No. 4, pp. 445-454, Bingley.

22. Stevanović, N., Malinić, D., Milićević, V. (2008): Upravljačko računovodstvo (ISBN: 978-86-403-0266-3)., CID, Ekonomski fakultet, Beograd.

23. Taylor, A., Rafai S. (2003): Strategic Budgeting A Case Study and Proposed Framework, Management Accounting Quarterly, Institute of Management Accounting, Vol. 5, No. 1, pp. 1-10, Montvale.

24. Toit, E., Hopkins, A., Oosthuizen, Qual-Enoo, A., Smith, C. (2007): Cost and Management Accounting: Fresh Perspectives (ISBN 978 186891 5361). Pearson, Cape.

25. Tompkins, J., Harmelink, D. (2004): The Supply Chain Handbook, (ISBN 1-930426-03-8). Tompkins Press, Orlando.

26. Vasiljević, Z., Savić, B. (2013): Knowledge as a source of competitive advantage of the agricultural enterprises, Thematic Proceedings "Sustainable Agriculture and Rural Development in Terms of the Republic of Serbia Strategic Goals Realization within the Danube Region-Achieving Regional Competitiveness", December 5-7th 2013, Topola - Serbia, Institute of Agricultural Economics, Belgrade, Serbia, pp. 816-832.

27. Visner, P. (2010): Linking Supply Chain Performance to a Firm's Financial Performance, p. 19, part 6, Beyonce the Basic: The Integrated supply chain. available at:http://www.scmr.com/article/linking_supply_chain_performance to a firms financial performance, accessed: 27.02.2015. 


\title{
ULOGA I ZNAČAJ STRATEGIJSKOG BUDŽETIRANJA ZA KONKURENTNOST AGROBIZNIS LANACA SNABDEVANJA
}

\author{
Bojan Savič́, Zorica Vasiljević ${ }^{6}$, Nikola Popovic ${ }^{7}$
}

\begin{abstract}
Sažetak
Rapidni izazovi i promene koje su sastavni deo poslovnog ambijenta zahtevaju da preduzeća pažljivo planiraju svoje poslovanje, kao i da procene verovatnoću nastanka $i$ ishod budućih događaja. Značaj navedenog pristupa još više dolazi do izražaja u domenu agrosektora koji, uz brojne specifičnosti i ograničenja svojstvena samoj poljoprivrednoj delatnosti, odlikuju i sve nepovoljniji uslovi poslovanja. Reč je pre svega o rastućim troškovima poslovanja s jedne $i$ nesrazmerne promene u visini prodajnih cena poljoprivrednih proizvoda na drugoj strani. Preduzeća formiraju lanac snabdevanja kako bi redukovala rizik i neizvesnost, realizovala proizvodnju kvalitetnih proizvoda po konkurentnim cenama, očuvala i povećala tržišno učešće. Realizacija tako složenih ciljeva zahteva adekvatan pristup procesu budžetiranja. Cilj rada je da osvetli značaj, domete i izazove budžetiranja kao instrumenta upravljačkog računovodstva i strategijskog budžeta za potrebe podrške menadžmentu u naporima sticanja i unapređenja konkurentnosti čitavog lanca snabdevanja.
\end{abstract}

Ključne reči: upravljačko računovodstvo, strategijski budžet, lanac podrške, agrobiznis sektor, konkurentnost.

5 Asistent, dr Bojan Savić, Univerzitet u Beogradu, Ulica Nemanjina br. 6, 11080 Beograd Zemun, Republika Srbija, Telefon: +381 112615315 /Ext. 211, E-mail: bsavic@agrif.bg.ac.rs

6 Redovni profesor, dr Zorica Vasiljević, Univerzitet u Beogradu, Ulica Nemanjina br. 6, 11080 Beograd Zemun, Republika Srbija, Telefon: +381 112615315 /Ext.412, E-mail: vazor@agrif.bg.ac.rs

7 Asistent, mr Nikola Popović, Univerzitet u Beogradu, Ulica Nemanjina br. 6, 11080 Beograd Zemun, Republika Srbija, Telefon: +381 112615315 /Ext. 215, E-mail: nikpop@agrif.bg.ac.rs 